\title{
PENGARUH METODE SHOW AND TELL TERHADAP KEPERCAYAAN DIRI ANAK KELOMPOK A TAMAN KANAK-KANAK GUGUS VII KECAMATAN BULELENG
}

\author{
Ni Kadek Ayu Antini ${ }^{1}$, Mutiara Magta ${ }^{2}$, Putu Rahayu Ujianti ${ }^{3}$ \\ 123Jurusan Pendidikan Dasar \\ Universitas Pendidikan Ganesha \\ Singaraja, Indonesia \\ e-mail: ayutini988@gmail.com
}

\begin{abstract}
Abstrak
Penelitian ini bertujuan untuk mengetahui perbedaan yang signifikan kepercayaan diri antara anak yang distimulasi metode show and tell dengan anak yang distimulasi metode konvensional kelompok A Taman Kanak-kanak Gugus VII Kecamatan Buleleng tahun pelajaran 2018/2019. Jenis penelitian ini adalah quasi eksperimen dengan rangcangannon-equivalen post test only control group design. Populasi penelitian ini adalah seluruh anak kelompok A Taman Kanak-kanak Gugus VII Kecamatan Buleleng tahun pelajaran 2018/2019, yang berjumlah 157 anak. Teknik pengambilan sampel dalam penelitian ini menggunakan teknik radom sampling. Sampel penelitian ini adalah eksperimen pada kelompok A1 TK Diponegoro yang berjumlah 20 anak dan kontrol pada kelompok A1 di TK Lab Undiksha yang berjumlah 17 anak. Uji hipotesis menggunakan uji-t dengan taraf signifikan $5 \%$ dan $\mathrm{dk}=2,03$ dengan demikian thitung $>t_{\text {tabel }}(7,43>2,03)$ maka $\mathrm{H}_{1}$ diterima dan $\mathrm{H}_{0}$ ditolak sehingga hasil penelitian menunjukan terdapat perbedaan kepercayaan diri antara anak yang distimulasi metode show and tell dengan anak yang distimulasi metode konvensional kelompok A Gugus VII Kecamatan Buleleng tahun pelajaran 2018/2019. Dengan demikian metode show and tell berpengaruh terhadap kepercayaan diri anak kelompok A Taman Kanak-kanak Gugus VII Kecamatan Buleleng tahun pelajaran 2018/2019.
\end{abstract}

Kata-kata Kunci: kepercayaan diri, metode show and tell

\begin{abstract}
This study aimed at determining the significant differences in self-confidence between the children who were stimulated by show and tell methods and the children who were stimulated by conventional method in group A Taman Kanak-kanak Gugus VII Buleleng Sub-district in academic year 2018/2019. This study used a quasi-experimental with non-equivalent design especially post-test only control group design. The population of this study was all children in group A Taman Kanak-kanak Gugus VII Buleleng Sub-district in academic year 2018/2019 which consisted of 157 children. The sampling technique used in this study was random sampling technique. The sample of this study was experiment in group A1 at TK Diponegoro which consisted of 20 children and control in group A1 at TK Lab Undiksha which consisted of 17 children. The hypothesis testing used t-test with a significant level of $5 \%$ and $\mathrm{dk}=2.03$, thus tcount $>$ ttable $(7.43>2.03)$ then $\mathrm{H} 1$ was accepted and $\mathrm{H} 0$ was rejected so the results showed that there were differences in selfconfidence between the children who were stimulated by show and tell methods with the children who were stimulated by conventional method in group A Gugus VII Buleleng Sub-district in academic year 2018/2019. Therefore, show and tell method had effect with self-confidence of children in group A Taman Kanak-kanak Gugus VII Buleleng Sub-district in academic year 2018/2019.
\end{abstract}

Keywords: self-confidence, show and tell method 


\section{PENDAHULUAN}

Anak usia dini merupakan generasi yang akan menjadi penerus bangsa. Pada usia ini juga disebut usia kritis dan sekaligus strategis dalam proses pendidikan yang dapat mempengaruhi proses serta hasil pendidikan pada tahap selanjutnya. Isjoni (dalam Wiyani, 2013) PAUD menyatakan bahwa sebagai bentuk layanan pendidikan yang diberikan kepada anak sejak lahir hingga usia enam tahun dengan cara memberikan rangsangan terhadap seluruh aspek perkembangan yang dimiliki oleh anak. Aspek perkembangan anak meliputi aspek perkembangan kognitif, bahasa, fisik motorik, sosial-emosional, agama moral dan seni. Aspek-aspek perkembangan ini berpengaruh dikehidupan anak dimasa dewasa.

Anak perlu adanya interaksi, adaptasi dan berkomunikasi dengan lingkungan, maka aspek perkembangan sosial-emosional anak dalam berperilaku dan bersikap harus dibiasakan. Hal ini agar anak berperilaku dan bersikap sesuai dengan nilai-nilai yang ada di masyarakat. Menurut Susanto (2011:134) "perilaku sosial dan emosional yang diharapkan dari anak usia dini adalah perilaku-perilaku yang baik, seperti kedisiplinan, kemandirian, tanggung jawab, percaya diri, jujur, adil, setia kawan, sifat kasih sayang terhadap sesama, dan memiliki toleransi yang tinggi". Menurut Romadhini dan Julianto (2016) "salah satu perilaku sosial-emosional yang memiliki peranan penting dalam kehidupan anak yaitu rasa percaya diri".

Menurut Rahayu (2013:58) "kepercayaan diri perlu dimiliki setiap anak agar anak mampu mengatasi setiap tantangan serta problematika yang akan dihadapi nanti. Erikson (dalam Romadhini dan Julianto, 2016) menyatakan bahwa pada usia 4 sampai 5 tahun anak masuk tahap psikososial pertama yang dialami dalam kehidupannya, dan kepercayaan diri yang dimiliki melibatkan rasa nyaman secara fisik dan tidak ada rasa takut atau kecemasan akan masa depan. Auerbach (dalam Susanto, 2011) menyatakan bahwa salah satu keterampilan anak usia empat tahun tentang perilaku sosial-emosional yakni percaya diri sepenuhnya pada kemampuan sendiri untuk melakukan segalanya, namun kenyataan dilapangan tidak seperti yang diharapkan. Di sekolah Taman Kanak-kanak guru sering hanya menitik beratkan pada program akademik (calistung) sehingga mengabaikan kemampuan anak yang lain, seperti kepercayaan diri. Jika anak memiliki kepercayaan diri yang rendah maka anak cenderung menghindar dari setiap kegiatan yang akan diberikan. Oleh karena itu, setiap pendidik perlu menanamkan kepercayaan diri kepada anak sejak dini. Tanpa dibekali rasa kepercayaan diri yang kuat, anak akan tumbuh menjadi pribadi yang lemah, manja dan pemalu. Selain itu kepercayaan diri juga dapat membantu anak untuk lebih mandiri.

Membentuk kepercayaan diri anak tidak bisa dilakukan secara instan, disini memerlukan sebuah proses dalam menumbuhkannya. Membentuk kepercayaan diri anak dilakukan dengan sering memberikan kesempatan dan kepercayaan kepada anak untuk melakukan aktivitas bantu diri dalam kehidupan sehari-hari, seperti makan sendiri maupun berinteraksi. Dengan memberikan kesempatan pada anak maka secara tidak langsung dapat menumbuhkan kepercayaan diri pada anak, karena anak diberi kesempatan untuk menyelesaikan sebuah tantangan yang akan terjadi pada dirinya. Angelis (dalam Rahayu, 2013) menyatakan bahwa kepercayaan diri merupakan hal dimana anak mampu menyalurkan segala sesuatu yang diketahui dan dikerjakan. Pernyataan tersebut kemudian diperkuat oleh Rahayu (2013:63) "anak dapat dikatakan percaya diri jika anak berani melakukan sesuatu hal yang baik bagi dirinya sesuai dengan pengetahuan dan kemampuan diri".

Hanisah (dalam Abubakar dan Sinta, 2018) menyatakan bahwa orang yang memiliki rasa percaya diri memiliki keyakinan bahwa dirinya mampu melakukan tugas-tugas yang harus dikerjakan dan menyelesaikan dengan cara yang kreatif dan sikap positif terhadap kemampuan yang ada pada dirinya. Hakim (dalam Rahayu, 2013) menyatakan bahwa kepercayaan diri adalah keyakinan seseorang terhadap segala aspek kelebihan yang dimilikinya dan keyakinan tersebut membuatnya merasa mampu untuk bisa mencapai berbagai tujuan hidup. Berdasarkan pemaparan teori-teori tersebut dapat disimpulkan bahwa kepercayaan diri pada anak yaitu keyakinan yang dimiliki oleh anak akan kemampuan dirinya dalam menghadapi masalah, mampu menyesuaikan diri dan mampu menyelesaikannya dengan bersikap tenang.

Kumara (dalam Hidayat dan Bashori, 2016) menyatakan bahwa aspek-aspek kepercayaan diri pada anak yaitu kemampuan menghadapi masalah, bertanggung jawab, 
kemampuan dalam bergaul dan kemampuan menerima kritik. Yoder dan Proctor (dalam Olivantina dan Suparno, 2018) menyatakan bahwa ciri anak yang memiliki kepercayaan diri tinggi jika anak memiliki kemampuan untuk bersikap tegas, teguh pada keyakinannya, mudah bergaul, bertanggung jawab, energik dan tidak mudah putus asa, dapat bekerja sama, serta mempunyai jiwa pemimpin. Lindenfield (dalam Wahyuni dan Nasution, 2017) menyatakan bahwa faktor yang membangun kepercayaan diri anak, yakni cinta, rasa aman, model peran/teladan, hubungan, kesehatan, sumber daya/fasilitas, dukungan dan upah atau hadiah. Menurut Wahyuni dan Nasution (2017) "gejala anak yang memiliki kepercayaan diri rendah adalah anak yang menghindari tugas, ragu-ragu, pesimis, pendiam, menutup diri, dan sering meminta bantuan orang lain". Susanto (2011:10-12) menyatakan,

cara untuk menumbuhkan kepercayaan diri anak yaitu katakan kita menyayangi minimal satu kali dalam sehari, tanggapi keluhan anak secara serius, biarkan anak melakukan kesalahan, tertawalah bersama, pujilah setiap usahanya, biarkan anak mengerjakan tugas sederhana, jagalah rahasia anak, sediakan waktu berkualitas dengan anak, bantu anak berpenampilan dan berperilaku yang baik, dan perkenalkan anak pada berbagai kegiatan.

Berdasarkan hasil observasi yang dilakukan pada tanggal 28 Januari 2019 sampai 10 Februari 2019 kelompok A di TK Lab Undiksha, TK Santa Maria, TK Diponegoro, TK Weda Purana, TK Immanuel, dan TK Bina Putra yang tergabung dalam satuan Gugus yaitu Taman Kanak-kanak Gugus VII Kecamatan Buleleng, diperoleh informasi bahwa kepercayaan diri pada anak kelompok A sudah distimulasi oleh guru namun masih ada beberapa anak kepercayaan dirinya perlu lebih dioptimalkan. Hal ini nampak dari ada beberapa anak yang tidak mau maju ke depan kelas saat diberikan kesempatan tampil, kemudian saat diberikan pertanyaan anak tidak menjawab kadang-kadang menjawab dengan suara terbata-bata seperti gagap padahal tidak mengalami gangguan pada alat bicaranya, jarang mengajukan pertanyaan saat proses pembelajaran padahal anak belum paham apa yang dijelaskan guru, anak canggung dalam bergaul dengan temannya, dan masih banyak lagi perilaku kepercayaan diri anak yang perlu diperbaiki. Dari hasil pengamatan di dalam proses pembelajaran saat observasi, anak yang sering distimulasi untuk percaya diri hanya anak yang sering angkat tangan untuk menjawab dan tampil di depan kelas dan inipun jarang dilakukan.

Masalah tersebut harus segera ditangani karena kepercayaan diri penting dimiliki setiap anak agar tidak menghambat anak dalam bersosialisasi dengan lingkungan sekitar. Faktor penyebab permasalahan tersebut dikarenakan guru dalam menstimulasi kepercayaan diri anak cenderung menggunakan metode konvensional dimana guru hanya memberikan instruksi atau ceramah kepada anak selama proses pembelajaran berlangsung sehingga anak jarang diberikan kesempatan untuk menyampaikan pendapat, tampil di depan kelas, dan mengajukan pertanyaan. Kegiatan pembelajaran ini cenderung dilakukan setiap hari oleh guru sehingga anak menjadi cepat bosan dan tidak memiliki semangat dalam proses pembelajaran. Salah satu alternatif untuk mengatasi permasalahan maka perlu dilakukan inovasi metode pembelajaran.

Solusi yang ditawarkan untuk menstimulasi kepercayaan diri anak yaitu metode show and tell. Menurut Pangestuti (2016) "metode show and tell adalah suatu metode pembelajaran dengan kegiatan anak menunjukan benda dan menyatakan pendapat, mengungkapkan perasaan, keinginan, maupun pengalaman terkait dengan benda tersebut". Metode show and tell diterapkan untuk melatih kemampuan berbahasa namun selain itu dapat juga melatih rasa percaya diri pada anak. Hal ini dipertegas oleh Patsalides (dalam Musfiroh, 2011) menyatakan bahwa salah satu manfaat metode show and tell yaitu meningkatkan rasa percaya diri pada anak (increase confidence). Ketika anak melakukan kegiatan show and tell teman-temannya akan memperhatikan dirinya sehingga rasa kepercayaan diri dan dihargai itu akan tumbuh. Anak merasa bahwa teman-temannya tertarik dan menunjukan rasa ingin tahu padanya.

Berdasarkan pendapat dari Pangestuti maka teori belajar yang mendasari metode show and tell yaitu teori belajar humanisme. Hal ini dikarenakan sesuai dengan prinsip-prinsip teori Roger dalam humanisme. Menurut Jamaris (2010) teori belajar humanisme yang didapat dari teori Roger bentuk tindakan dan pembelajaran menerapkan prinsip-prinsip yaitu memberi 
kesempatan kepada siswa untuk mengekspresikan pikiran dan perasaannya, untukmenginternalisasi kejadian-kejadian yang selama proses pendidikan dan pembelajaran terjadi, serta untuk tampil seperti dirinya sendiri dengan jati diri yang utuh. Metode show and tell juga bersumber dari teori belajar behaviorisme. Teori belajar behaviorisme berkaitan dengan stimulus respons (stimulusnya adalah metode show and tell dan responnya adalah kepercayaan diri).Menurut Khodijah (2017:65) "paragdigma behavioristik menekankan proses belajar sebagai perubahan relatif permanen pada perilaku yang dapat diamati dan timbul sebagai hasil pengalaman". Menurut Jamaris (2010) "teori belajar behaviorisme tentang psikologi perilaku didapat dari teorinya Skiner yang disebut dengan operant conditioning". Teori ini dilatar belakangi bahwa makhluk hidup yaitu manusia dan hewan selalu berada dalam proses operating (melakukan sesuatu) terhadap lingkungannya. Selama melakukan sesuatu terhadap lingkungan, makhluk hidup menemukan stimulus khusus yang disebut reinforcing stimulus atau stimulus pendorong. Stimulus ini dapat meningkatkan perilaku yang terjadi beberapa saat setelah stimulus tampil.Metode show and tell digunakan untuk merubah perilaku anak kurang memiliki kepercayaan diri menjadi memiliki kepercayaan diri pada teori belajar behaviorisme.

Metode show and tell diterapkan untuk melatih kemampuan berbahasa namun selain itu, dapat juga melatih rasa percaya diri pada anak. Hal ini dipertegas oleh Patsalides (dalam Musfiroh, 2011) menyatakan bahwa salah satu manfaat metode show and tell yaitu meningkatkan rasa percaya diri pada anak (increaseconfidence). Ketika anak melakukan kegiatan showandtell teman-temannya akan memperhatikan dirinya sehingga rasa kepercayaan diri dan dihargai itu akan tumbuh. Anak merasa bahwa teman-temannya tertarik dan menunjukan rasa ingin tahu padanya. Media yang digunakan untuk kegiatan show and tell adalah benda pribadi, makanan kesukaan, dan foto/gambar. Benda pribadi yang dimaksud yaitu benda yang dimiliki oleh anak misalnya alat permainan yang dimiliki/kesukaannya, boneka yang disukai, sepatu dan yang lainnya. Anak menggunakan media ini perlu adanya pengalaman sebelumnya terkait dengan media yang digunakan.

Metode show and tell dapat membantu guru untuk menstimulasi kepercayaan diri anak. Beberapa hasil penelitian relevan yang telah dilakukan oleh peneliti lain yaitu menurut Pangestuti (2016) "kemampuan berbicara anak meningkat dengan metode show and tell yang diterapkan". Menurut Permatasari (2018) "metode show and tell dapat meningkatkan kemampuan berbicara anak usia dini". Menurut Lestari, dkk (2017) "metode show and tell dapat meningkatkan keterampilan berkomunikasi anak usia dini". Menurut Romadhini dan Julianto (2016) "ada pengaruh yang signifikan dari penerapan metode show and tell diiringi musik terhadap kepercayaan diri anak kelompok A di TK Muslimah NU 82 Sambisari Sidoharjo". Hasil penelitian ini merekomendasikan bahwa metode show and tell dapat digunakan dalam menstimulasi kepercayaan diri anak.

Berdasarkan permasalahan di atas maka penelitian ini berjudul pengaruh metode show and tell terhadap kepercayaan diri anak kelompok A Taman Kanak-kanak Gugus VII Kecamatan Buleleng tahun pelajaran 2018/2019. Adapun rumusan masalah penelitian ini yaitu apakah terdapat perbedaan yang signifikan kepercayaan diri antara anak yang distimulasi metode show and tell dengan anak yang distimulasi metode konvensional kelompok A Taman Kanak-kanak Gugus VII Kecamatan Buleleng tahun pelajaran 2018/2019?. Tujuan penelitian ini yaitu untuk mengetahui perbedaan yang signifikan kepercayaan diri antara anak yang distimulasi metode show and tell dengan anak yang distimulasi metode konvensional kelompok A Taman Kanak-kanak Gugus VII Kecamatan Buleleng tahun pelajaran 2018/2019.

\section{METODE}

Penelitian ini dilaksanakan di Taman Kanak-kanak Gugus VII Kecamatan Buleleng yang terdiri dari 6 sekolah. Populasi yang digunakan pada penelitian ini adalah seluruh anak Taman Kanak-kanak Gugus VII Kecamatan Buleleng yang berjumlah 157 anak. Penelitian ini termasuk penelitian eksperimen semu (quasi eksperimen) dengan rancangan Non-equivalen Post Test Only Control Group Design. Rancangan ini disajikan dalam tabel 1. 
Tabel 1. Rancangan Penelitian

\begin{tabular}{ccc}
\hline Kelas & Perlakuan & Post-test \\
\hline Eksperimen & $\mathrm{X}$ & $\mathrm{O}_{1}$ \\
\hline Kontrol & - & $\mathrm{O}_{2}$
\end{tabular}

(Sumber: Agung, 2014: 163)

Teknik pengambilan sampel pada penelitian ini menggunakan random sampling. Sebelum menentukan sampel penelitian, dilakukan uji kesetaraan terhadap populasi penelitian. Untuk menghitung kesetaraan populasi digunakan analisis varian satu jalur (anava A). Adapun hasil perhitungan uji kesetaraan menggunakan analisis anava A pada taraf signifikansi $5 \%$, diperoleh nilai $F_{\text {hitung }}=0,34<\mathrm{F}_{\text {tabel }}=1,94$ dengan $\mathrm{db}_{\text {antar }}=9$ dan $\mathrm{db} \mathrm{b}_{\text {dal }}=147$. Sehingga kelompok dalam populasi dinyatakan setara. Setelah dilakukan uji kesetaraan, selanjutnya ditetapkan 2 sampel penelitian yaitu A1 TK Diponegoro yang berjumlah 20 orang anak sebagai kelompok eksperimen dan kelompok A1 TK Lab Undiksha yang berjumlah 17 orang anak sebagai kelompok kontrol.

Penelitian ini untuk mengetahui pengaruh satu variabel bebas dan variabel terikat. Variabel bebas dalam penelitian ini adalah metode show and tell dan variabel terikat kepercayaan diri anak. Metode pengumpulan data yang dilakukan dalam penelitian ini menggunakan metode observasi. Uji coba instrument pada penelitian ini menggunakan uji validitas isi, uji validitas empiris dan uji reliabilitas. Uji validitas isi menggunakan rumus gregory, uji validitas empiris menggunakan rumus korelasi product moment dan uji reliabilitas menggunakan alpha cronbach yang reliabilitas tinggi. Dalam menganalisis data menggunakan metode analisis statistik deskriptif yang bertujuan untuk mengetahui tinggi rendahnya data. Setelah dilakukan analisis statistik diskriptif selanjutnya akan dilakukan uji asumsi data yang terdiri dari uji normalitas menggunakan chi-square dan uji homogenitas menggunakan uji Fisher (F). Uji hipotesis pada penelitian ini menggunakan uji-t sampel tidak berkolerasi dengan menggunakan rumus polled varians.

\section{HASIL DAN PEMBAHASAN}

Berdasarkan analisis data yang dilakukan terhadap kepercayaan diri anak, diperoleh hasil seperti yang disajikan pada tabel 2 .

Tabel 2. Rekapitulasi Hasil Perhitungan Skor Kepercayaan Diri anak

\begin{tabular}{ccc}
\hline Statistik Deskriftif & Kelompok Eksperimen & Kelompok Kontrol \\
\hline Mean & 37 & 25,18 \\
\hline Median & 37,75 & 24,01 \\
\hline Modus & 40 & 22 \\
\hline Standar Deviasi & 4,70 & 4,89 \\
\hline Varians & 22,47 & 23,91 \\
\hline
\end{tabular}

Berdasarkan tabel 2, diketahui bahwa rata-rata skor kepercayaan diri anak yang distimulasi dengan metode show and tell lebih tinggi dibandingkan rata-rata skor kepercayaan diri anak yang distimulasi metode konvensional. Hal ini menunjukan bahwa metode show and tell lebih unggul daripada metode konvensional untuk meningkatkan kepercayaan diri anak. Setelah diketahui mean, median dan modus pada kelompok eksperimen, selanjutnya sebaran data disajikan dalam bentuk grafik polygon seperti gambar 1 . 


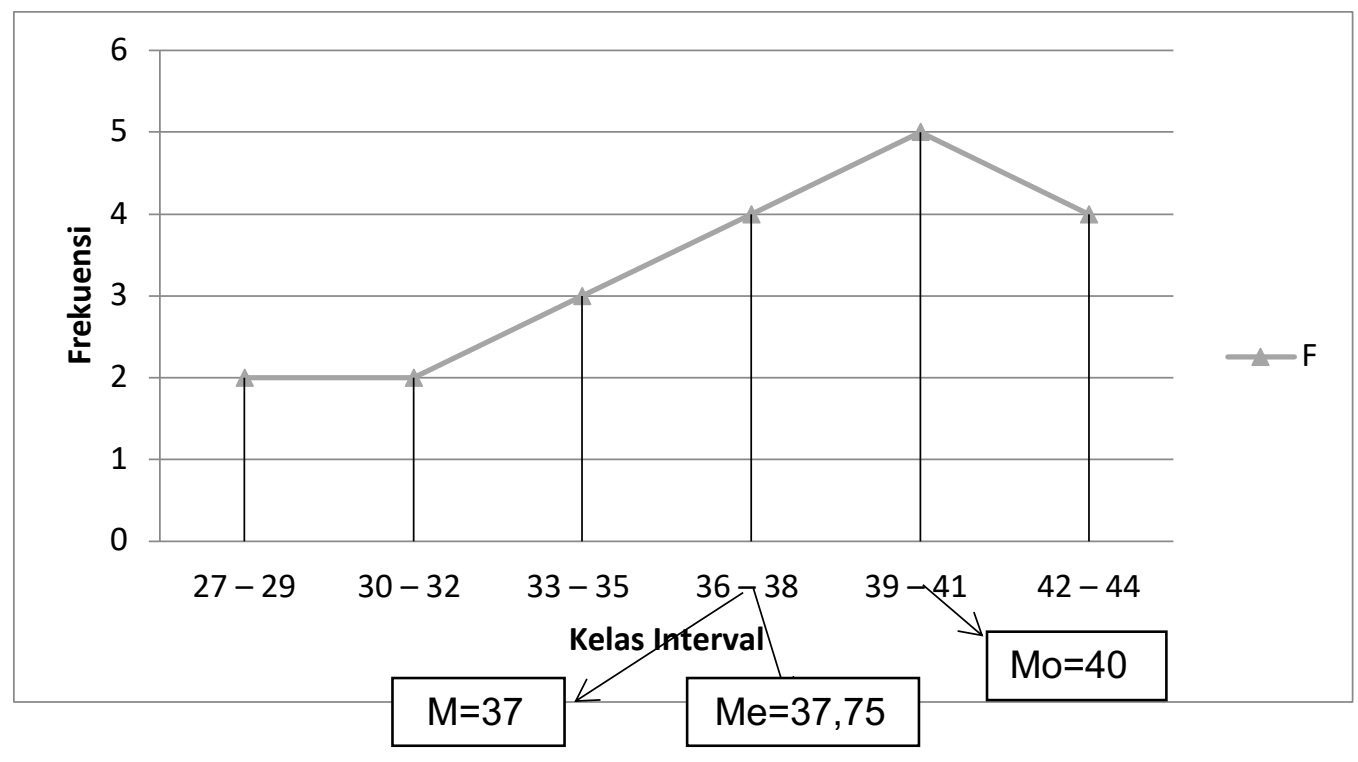

Gambar 1

Grafik Polygon Data Kepercayaan Diri Anak Kelompok Eksperimen

Gambar grafik di atas menunjukan bahwa harga statistik Mo>Me>M dan tergolong grafik juling negatif. Berdasarkan gambar tersebut dapat diinterpretasikan bahwa skor kepercayaan diri anak cenderung tinggi.

Setelah diketahui mean, median dan modus pada kelompok kontrol, selanjutnya sebaran data disajikan dalam bentuk grafik polygon seperti gambar 2 .

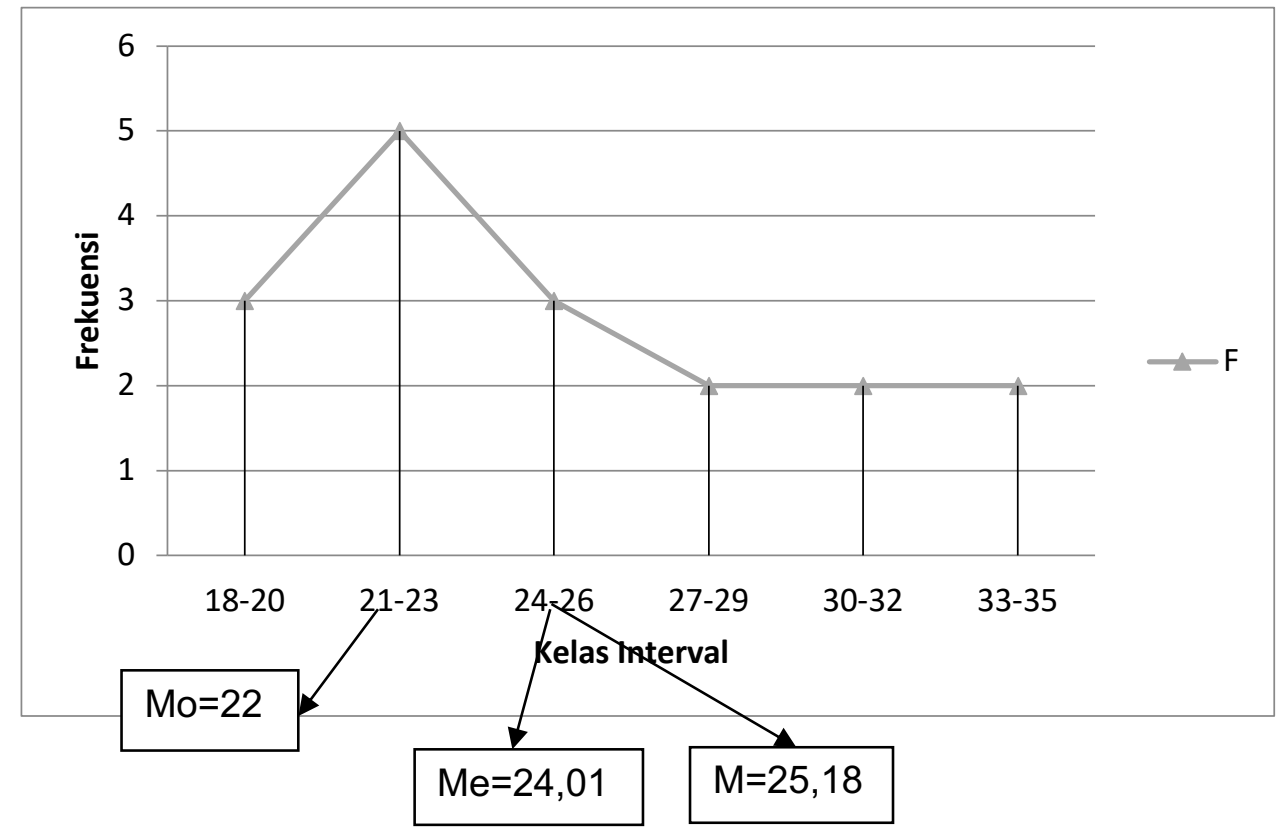

Gambar 2

Grafik Polygon Data Kepercayaan Diri Kelompok Kontrol

Gambar grafik di atas menunjukan bahwa harga statistik $\mathrm{Mo}<\mathrm{Me}<\mathrm{M}$ dan tergolong grafik juling positif. Berdasarkan gambar tersebut dapat diinterpretasikan bahwa skor kepercayaan diri anak cenderung rendah. 
Selanjutnya untuk mengetahui perbedaan kepercayaan diri anak melalui pengujian hipotesis,terlebih dahulu dilakukan uji prasyarat analisis yaitu uji normalitas dan uji homogenitas. Ringkasan hasil uji normalitas kepercayaan diri anak dapat dilihat pada tabel 3.

Tabel 3. Rangkuman Hasil perhitungan Uji normalitas Kelompok Eksperimen dan Kelompok Kontrol

\begin{tabular}{cccccc}
\hline No & Kelompok Data & $\mathrm{N}$ & $\mathrm{X}^{2}{ }_{\text {hitung }}$ & $\mathrm{X}^{2}$ tabel & Status \\
\hline 1 & Eksperimen & 20 & 2,20 & 11,07 & Normal \\
\hline 2 & Kontrol & 17 & 3,78 & 11,07 & Normal \\
\hline
\end{tabular}

Dari tabel di atas maka dapat diketahui hasil perhitungan post-test kepercayaan diri anak kelompok eksperimen dan kontrol berdistribusi normal. Selanjutnya akan dilanjutkan dengan uji homogenitas varians. Uji homogenitas varians dapat dilihat pada tabel 4.

Tabel 4. Rangkuman Hasil Uji Homogenitas Varians

\begin{tabular}{cccc}
\hline Sumber Data & $\mathrm{F}_{\text {hitung }}$ & $\mathrm{F}_{\text {tabel }}(5 \%)$ & Status \\
\hline $\begin{array}{c}\text { Post-test Kelompok Eksperimen } \\
\text { dan Kelompok Kontrol }\end{array}$ & 1,06 & 4,12 & Homogen \\
\hline
\end{tabular}

Setelah semua pengujian asumsi dilaksanakan, selanjutnya dilakukan pengujian hipotesis dengan uji-t. Hasil pengujian hipotesis dengan uji-t dapat dilihat pada tabel 5.

Tabel 5. Rangkuman Hasil Uji Hipotesis

\begin{tabular}{cccccccc}
\hline Kelompok & $\mathrm{N}$ & $\mathrm{dk}$ & $\mathrm{M}$ & Varians & $\mathrm{t}_{\text {hitung }}$ & $\mathrm{t}_{\text {tabel }}$ & Keterangan \\
\hline Eksperimen & 20 & \multirow{2}{*}{35} & 37 & 22,47 & \multirow{2}{*}{7,43} & \multirow{2}{*}{2,03} & $\begin{array}{c}\text { H1 Diterima } \\
\text { dan H0 Ditolak }\end{array}$ \\
Kontrol & 17 & & 25,18 & 23,91 & & &
\end{tabular}

Berdasarkan analisis di atas, didapatkan thitung sebesar 7,43 . thitung tersebut selanjutnya dibandingkan dengan $t_{\text {tabel }}$ pada taraf signifikansi $5 \%$ dengan $d k=n_{1}+n_{2}-2=20+17-2=35$ adalah sebesar 2,03. Hasil tersebut menunjukan bahwa $t_{\text {hitung }}(7,43)>t_{\text {tabel }}(2,03)$, sehingga $\mathrm{H}_{1}$ diterima dan $\mathrm{H}_{0}$ ditolak. Ini berarti terdapat perbedaan yang signifikan kepercayaan diri antara anak yang distimulasi metode show and tell dengan anak yang distimulasi metode konvensional kelompok A Taman Kanak-kanak Gugus VII Kecamatan Buleleng tahun pelajaran $2018 / 2019$.

Berdasarkan hasil temuan pada kedua kelompok diperoleh bahwa jika kedua kelompok yang awalnya memiliki kepercayaan diri setara, lalu setelah diberikan perlakukan pada kelompok eksperimen maka diperoleh nilai kepercayaan diri anak mengalami perbedaan yang signifikan. Kepercayaan diri anak kelompok eksperimen lebih baik daripada kepercayaan diri anak kelompok kontrol. Hal ini dapat dilihat pada rata-rata kelompok eksperimen dan kelompok kontrol.

Perbedaan kepercayaan diri anak disebabkan karena adanya metode show and tell yang diterapkan pada kelompok eksperimen. Hal ini dikarenakan oleh beberapa hal diantaranya metode show and tell mengajak semua anak untuk terlibat aktif dalam proses kegiatan belajar, sehingga anak tidak hanya sebagai penonton atau pendengar saja, melainkan anak ikut terlibat dalam kegiatan yang akan dilakukan sehingga anak tidak merasa bosan dalam mengikuti proses pembelajaran. Metode show and tell dapat membentuk perilaku percaya diri melalui kegiatan yang menyenangkan dan menarik bagi anak. Hal ini sesuai dengan pendapat Rohmadhini dan Julianto (2016) "metode show and tell merupakan metode 
yang menarik dan bisa diterapkan dalam pembelajaran karena dengan menggunakan metode ini akan tercipta suasana belajar yang menyenangkan dan menarik bagi anak". Selain itu pembelajaran dengan metode show and tel/tidak membuat anak bosan.

Pembelajaran dengan menggunakan metode show and tell mengajak anak secara langsung terlibat dalam proses kegiatan bercerita di depan kelas mengenai benda yang dibawanya. Benda atau media yang digunakan untuk kegiatan show and tell adalah benda pribadi,makanan kesukaan dan foto/gambar. Benda pribadi yang dimaksud, yaitu benda yang dimiliki anak seperti alat pemainan, boneka, sepatu dan yang lainnya. Melalui benda atau media yang dibawanya dapat mempermudah anak untuk bercerita ke teman-temannya. Hal ini sesuai dengan pendapat Musfiroh (2011) "penggunaan media konkret mempermudah anak untuk menjelaskan dan bercerita". Media konkret yang dimaksud yaitu media yang bisa dideskripsikan melalui pancaindra anak. Hal ini sesuai dengan langkah metode show and tell dimana anak bercerita dengan posisi bendiri dan menunjukan benda yang dibawanya kemudian menceritakan pengalaman yang didapatkan bersama dengan bendanya.

Anak yang distimulasi dengan metode show and tell kepercayaan dirinya lebih baik dikarenakan saat anak melakukan kegiatan show and tell teman-temannya akan memperhatikan dirinya sehingga rasa kepercayaan diri dan dihargai itu akan tumbuh. Anak merasa bahwa teman-temannya tertarik dan menunjukan rasa ingin tahu padanya. Hal ini sesuai dengan pendapat Zingher (dalam Ningsih, 2014) yang menyatakan bahwa saat anak melakukan show and tell akan menjadi momen yang bersinar bagi anak karena kepercayaan dirinya meningkat.

Hasil penelitian ini juga sejalan dengan penelitian yang dilakukan oleh Romadhini dan Julianto (2016) yang menyatakan bahwa metode show and tell diiringi musik dapat meningkatkan kepercayaan diri. Hasil yang didapatkan yaitu ada pengaruh yang signifikan penerapan metode show and tell diiringi musik terhadap kepercayaan diri anak kelompok A. Hasil penelitian ini merekomendasikan bahwa metode show and tell dapat digunakan dalam menstimulasi kepercayaan diri anak.

Lain halnya dengan pembelajaran pada kelompok eksperimen, kegiatan pembelajaran pada kelompok kontrol masih perlu dioptimalkan untuk menstimulasi kepercayaan diri anak. Hal ini dikarenakan guru dalam menstimulasi kepercayaan diri anak cenderung hanya memberikan instruksi atau ceramah kepada anak selama proses pembelajaran berlangsung sehingga anak jarang diberikan kesempatan untuk menyampaikan pendapat, tampil di depan kelas, dan mengajukan pertanyaan. Guru memberikan kegiatan pembelajaran ini setiap hari sehingga anak menjadi cepat bosan dan tidak memiliki semangat dalam proses pembelajaran. Metode konvensional tidak cocok untuk membentuk sikap atau perilaku anak yang lebih baik. Hal ini dikarenakan pembelajarannya bersifat satu arah, anak sebagai penerima pembelajaran tanpa diberikan kesempatan langsung untuk belajar.

Berdasarkan paparan di atas, terlihat bahwa metode show and tell dapat dijadikan sebagai salah satu alternatif untuk menstimulasi kepercayaan diri anak. Semua anak diberikan kesempatan untuk tampil dan menceritakan pengalaman bersama dengan benda yang dibawanya. Selain itu semua anak distimulasi untuk bisa bertanya dan menjawab pertanyaan yang diberikan oleh guru maupun temannya. Dengan ini maka semua anak akan menjadi aktif dalam mengikuti proses pembelajaran. Jadi, dapat disimpulkan bahwa metode show and tell berpengaruh terhadap kepercayaan diri anak kelompok A Taman Kanak-kanak Gugus VII Kecamatan Buleleng tahun pelajaran 2018/2019.

\section{SIMPULAN DAN SARAN}

Berdasarkan pemaparan hasil penelitian dan pembahasan maka dapat disimpulkan bahwa terdapat perbedaan yang signifikan kepercayaan diri antara anak yang distimulasi metode show and tell dengan anak yang distimulasi metode konvensional kelompok A Taman Kanak-kanak Gugus VII Kecamatan Buleleng tahun pelajaran 2018/2019. Hal ini terlihat dari hasil uji-t diperoleh thitung adalah 7,43 sedangkan ttabel dengan taraf signifikan $5 \%$ dan dk $=$ $n 1+n 2-2=20+17-2=35$ adalah 2,03. Dengan demikian, $t_{\text {hitung }}(7,43)>t_{\text {tabel }}(2,03)$ maka $\mathrm{H}_{1}$ diterima dan $\mathrm{H}_{0}$ ditolak. Metode show and tell berpengaruh terhadap kepercayaan diri anak 
dikarenakan metode show and tell dapat memotivasi anak untuk berbuat sesuatu yang mendorong anak untuk lebih memiliki kepercayaan diri akan kemampuan yang dimilikinya.

Berdasarkan hasil penelitian, pembahasan dan simpulan di atas penulis mengajukan saran sebagai berikut. Bagi kepala sekolah, agar hasil ini dapat dijadikan bahan pertimbangan untuk merancang program pembelajaran sehingga dapat meningkatkan kepercayaan diri anak. Bagi guru, agar dalam melaksanakan proses pembelajaran hendaknya menerapkan suatu metode pembelajaran yang inovatif sesuai dengan karakteristik anak usia dini untuk meningkatkan kepercayaan diri anak. Bagi peneliti, yang berminat untuk mengadakan penelitian lebih lanjut tentang metode show and tell dalam menstimulasi kepercayaan diri anak agar memperhatikan kekurangan dalam penelitian ini sebagai bahan pertimbangan untuk perbaikan dan penyempurnaan penelitian yang dilaksanakan.

\section{DAFTAR PUSTAKA}

Abubakar, Sitti Rahmaniar dan Dewi Widiastuti Sinta. (2018). "Meningkatkan Kepercayaan Diri Anak Melalui Kegiatan Mendongeng Di TK Sangia Jampaka Kecamatan Mawasangka. Jurnal Smart PAUD, Volume 1, Nomor 2.

Agung, A.A. Gede. 2014. Metodologi Penelitian Pendidikan. Singaraja: Aditya Media Publishing.

Hidayat, Komaruddin dan Khoiruddin Bashori. 2016. Psikologi Sosial. Jakarta: Erlangga.

Jamaris, Martin. 2010. Orientasi Baru Dalam Psikologi Pendidikan. Jakarta: Yayasan Penamas Murni.

Khodijah, Nyanyu. 2017. Psikologi Pendidikan. Jakarta: PT Raja Grafindo Persada.

Musfiroh, Tadkiroatum. (2011). "Show and Tell Edukatif untuk mengembangkan Empati, Afiliasi-Resolusi Konflik, dan Kebiasaan Positif Anak Usia Dini”. Jurnal Kependidikan, Volume 41, Nomor 2 (hlm. 129-143).

Ningsih, Okki Ristya Mutasi. 2014. Meningkatkan Percaya Diri Melalui Metode Show And Tell Pada Anak Kelompok A Tk Marsudi Putra, Dagaran, Palbapang, Bantul, Yogyakarta. Skripsi. Fakultas IImu Pendidikan Universitas Negeri Yogyakarta. Tersedia pada file:///E:/DATA\%20SEMESTER\%20VIII/MATERI\%20PERCAYA\%20DIRI/Percaya\%20di ri/NINGSIH.pdf (diakses tanggal 25 Oktober 2018).

Olivatina, Rara Agista dan Suparno. (2018). "Peningkatan Kepercayaan Diri Anak Melalui Metode Talking stick". Jurnal PAUD, Volume 12, Edisi 2.

Pangestuti, Laras. (2016). "Pengaruh Metode Show and Tell Terhadap Kemampuan Berbicara Anak Kelompok A di Taman Kanak-kanak". Jurnal PAUD, Edisi 9.

Permatasari, Ni Kadek Tania. 2018. Pengaruh Metode Show And Tell Terhadap Kemampuan Berbicara Anak Kelompok B. E-Jurnal PAUD Undiksha, Volume 6, Nomor 2.

Rahayu, Aprianti Yofita. 2013. Menumbuhkan Kepercayaan Diri Melalui Kegiatan Bercerita. Jakarta: PT Indeks.

Rahayu, Novita Cristy. (2013). "Pengaruh Penggunaan Metode Bercerita Terhadap Rasa Percaya Diri Anak di TK Dharma Wanita Persatuan Kalipadang Kecamatan Benjeng Kabupaten Gresik". Jurnal Unesa, Volume 2, Nomor 2. 
Romadhini, Nur Endah dan Julianto. (2016). "Pengaruh Penerapan Metode Show and Tell Diiringi Musik Terhadap Kepercayaan Diri Anak Kelompok A".Jurnal PAUD Teratai, Volume 05, Nomor 02 (hlm. 39-43).

Susanto, Ahmad. 2011. Perkembangan Anak Usia Dini. Jakarta: Kencana.

Wahyuni, Sri dan Rukiah Nur Badri Nasution. (2017). "Upaya Meningkatkan Kepercayaan Diri Anak Usia Dini Melalui Metode Bercerita Di Kelompok B RA An-Nida". Jurnal PGRA, Volume 5, Nomor 2.

Wiyani, Novan Ardy. 2013. Bina Karakter Anak Usia Dini: Panduan Orangtua \& Guru dalam Membentuk Kemandirian \& Kedisiplinan Anak Usia Dini. Jogjakarta: AR-RUZZ MEDIA. 